\title{
DESAIN APLIKASI TRACER STUDY BERBASIS WEB MENGGUNAKAN LARAVEL FRAMEWORK
}

\author{
Muhamad Yusup*1, Diah Aryani ${ }^{2}$, Suhendi $^{3}$ \\ ${ }^{1,3}$ Program Studi Teknik Informatika Universitas Raharja, ${ }^{2}$ Program Studi Sistem Komputer \\ Universitas Raharja \\ e-mail: yusup@ raharja.info-1,diah.aryani@ raharja.info ${ }^{2}$, suhendi@ raharja.info ${ }^{3}$
}

\begin{abstract}
Learning Evaluation conducted includes internal evaluations and external evaluations of learning management. One form of internal evaluation carried out is a comprehensive review of the curriculum. For this reason, one of them is by tracer study. Tracer Study is a tracking study conducted by alumni after graduation, which aims to find out the educational outcomes in the form of transitions from the world of higher education to the world of work, mastery of competencies, evaluation of learning processes and excavation of graduate sociobiographies. However, the availability of study data is incomplete and difficult to obtain. Some of what has been done is to use social media, e-mail and by distributing cover letters in the form of questionnaires to alumni manually. For this reason, it is necessary to develop a tracer study application with a website using Laravel Framework which has advantages, namely with MVC (model view controller) using a software approach that separates logic and presentation applications so that the time used in developing this application becomes faster.
\end{abstract}

Keywords - Tracer Study, Model View Controller, Laravel Framework

\begin{abstract}
Abstrak
Evaluasi Pembelajaran yang dilakukan meliputi evaluasi internal dan evaluasi eksternal terhadap pengelolaan pembelajaran. Salah satu bentuk evaluasi internal yang dilakukan adalah peninjauan terhadap kurikulum secara komprehensip. Untuk itu salah satunya adalah dengan tracer study. Tracer Study merupakan studi pelacakan yang dilakukan kepada alumni setelah lulus, yang bertujuan untuk mengetahui outcome pendidikan dalam bentuk transisi dari dunia pendidikan tinggi ke dunia kerja, penguasaan terhadap kompetensi, evaluasi proses pembelajaran dan penggalian terhadap sosiobiografis lulusan. Namun demikian ketersediaan data studi tersebut tidak lengkap dan sulit diperoleh. Beberapa yang sudah dilakukan adalah menggunakan media sosial, email dan dengan menyebarkan surat pengantar berupa kuesioner kepada alumni secara manual. Untuk itu perlu dikembangkan aplikasi tracer study dengan website menggunakan Laravel Framework yang memiliki kelebihan yaitu dengan MVC (model view controller) menggunakan pendekatan perangkat lunak yang memisahkan aplikasi logika dan presentasi sehingga waktu yang digunakan dalam pengembangan aplikasi ini menjadi lebih lebih cepat.
\end{abstract}

Kata kunci-Tracer Study, Laravel Framework, Black Box Testing 


\section{PENDAHULUAN}

Pendidikan memiliki peran yang penting dalam mencerdaskan kehidupan bangsa, khususnya menghasilkan lulusan yang berkualitas, siap kerja ataupun lulusan yang siap membuka lapangan kerja yang bermanfaat bagi masyarakat. Seberapa besar kiprah lulusan dalam pembangunan dan apakah sesuai relevansi dengan pendidikannya dapat dilakukan dengan melakukan penelusuran terhadap alumni. Tracer study [1] merupakan studi pelacakan jejak lulusan/alumni yang dilakukan setelah lulus. Tracer study bertujuan untuk mengetahui outcome pendidikan bentuk transisi dari dunia pendidikan tinggi ke dunia kerja sedangkan output pendidikan yaitu penilaian diri terhadap penguasaan dan pemerolehan kompetensi serta input pendidikan berupa penggalian lebih lajut terhadap informasi sosiobiografis lulusan. Tracer Study Alumni atau STA [2] adalah dengan melakukan survey untuk mendapatkan informasi dari alumni dengan menggunakan quesioner online. Quesioner online digunakan untuk memperoleh karakteristik dan sosiologi, kegiatan pendidikan dan pengajaran di kampus, transisi kedunia kerja, pekerjaan dan kompetensi hubungan pekerjaan dengan program studi. Setelah informasi atau diperoleh selanjutnya dilakukan pengolahan data.

Aktifitas TSA yang dilakukan di Universitas Raharja belum maksimal dilakukan. Proses pengelolaannya membutuhkan waktu yang lama karena dilakukan secara manual. Ini yang menyebabkan kesulitan dalam melakukan studi penelusuran data alumni. Untuk melakukan aktifitas TSA menggunakan media sosial dan email serta menyebarkan surat yang ditujukan ke alamat rumah alumni. Penyebaran kuesioner cara ini kurang maksimal karena karena tidak menjangkau semua alumni. Selain itu masalah lain pada responden/alumni, dimana responden/alumni tidak mengisi dengan alasan tertentu sehingga sedikit yang mengisi kuesioner yang diterima kembali. Untuk mengukur indikator yang jelas tentang profile lulusan serta mendapatkan umpan balik dari menyedia lapangan kerja. Hasil dari tracer study diharapkan dapat membantu perguruan tinggi mengetahui posisi alumni atau lulusan yang diserap dalam dunia kerja dan menyiapkan lulusan sesuai dengan kompetensi yang diperlukan.

Berdasarkan uraian tersebut, penelitian ini bertujuan membuat rancangan sistem tracer study berbasis web menggunakan Laravel Framework [3]. Penelitian ini menggunakan Laravel Framework karena beberapa keunggulan. Keunggulan Laravel [4] diantaranya adalah expressif, simple (karena adanya Eloquent ORM), accessible (dibuat dengan dokumentasi yang selengkap mungkin). Selain itu di Laravel terdapat banyak fitur. Fitur tersebut diantaranya bundles (sebuah fitur dengan sistem pengemasan modular dan berbagai bundle telah tersedia untuk digunakan dalam aplikasi).

\section{METODOLOGI PENELITIAN}

Metode Penelitian yang digunakan dengan studi pustaka dengan melakukan kajian pustaka dari berbagai sumber yang berkaitan dengan permasalahan yang ada pada lingkup penelitian yaitu seputar tracer study. Untuk metode pengembangannya menggunakan prototype[5]. Berikut ini adalah metodologi yang digunakan dalam penelitian ini. Pengumpulan Kebutuhan Sistem Desain dan Prototyping Menguji Sistem Pengumpulan Kebutuhan. Pada tahap ini dilakukan identifikasi permasalahan dan alternatif pemecahan permasalahannya, termasuk identifikasi seluruh kebutuhan pengembangan sistem dilakukan dengan studi pustaka dan dengan wawancara. Sistem Desain dan Konstruksi. Pada tahap ini adalah hasil dari prototype berupa tampilan view yang sudah finalisasi kemudian dituangkan ke desain dan konstruksi dalam bahasa pemrograman dalam hal ini menggunakan bahasa pemrograman PHP dengan Laravel Framework yang memisahkan antara model, view dan controller. Pada tahap ini juga dirancang class diagram untuk mengetahui atribut dan method pada objek di aplikasi tracer studi. Prototyping. Prototyping yang dibangun adalah 
dengan membuat rancangan awal perangkat lunak yang berpusat tampilan view (format input dan output sistem serta graphic user interface), rancangan model dan rancangan controller yang saling berinteraksi. Menguji Sistem. Pada tahap ini setelah protopype selesai menjadi perangkat lunak maka selanjutnya dilakukan tahap pengujian dengan modul-modul yang siap digunakan.

\section{LANDASAN TEORI \\ Pengertian Aplikasi}

Pengertian aplikasi menurut Kamus Besar Bahasa Indonesia Aplikasi adalah penerapan dari rancang sistem untuk mengolah data yang menggunakan aturan atau ketentuan bahasa pemrograman tertentu. [6]

\section{Pengertian Tracer Study}

Tracer Study adalah studi pelacakan (tracer study) untuk mendapatkan hasil evaluasi kinerja lulusan dengan pihak pengguna, rata-rata waktu tunggu lulusan memperoleh pekerjaan pertama, prosentase lulusan yang bekerja pada bidang sesuai keahliannya, apakah lulusan memiliki himpunan alumni, apa aktivitas dan hasil kegiatan dari himpunan alumni terhadap kemajuan program studi" [7].

\section{Pengertian Laravel}

Laravel merupakan framework PHP open source yang dikembangkan oleh Tylor Otwell yang berada di bawah lisensi MIT yang bertujuan untuk mempermudah para developer untuk membuat web dengan sintaks yang sederhana, elegan, ekspresif dan juga menyenangkan[4].

\section{HASIL DAN PEMBAHASAN}

\section{Pengumpulan Kebutuhan}

Pengumpulan Kebutuhan dimulai dengan melakukan Analisa Permasalahan. Analisa Permasalahan menggunakan survei pendahuluan terhadap kebutuhan pengguna yang dipaparkan berikut ini.

1. Pihak universitas mengalami kesulitan dalam menelusuri data alumni. Kemudahan dalam melakukan penelusuran alumni.

2. Untuk melacak alumni, bagian kemahasiswaan kampus selama ini dilakukan secara manual. Kemudahan dalam pelacakan alumni menggunakan media aplikasi web dilakukan cara komputerisasi.

3. Pelacakan alumni masih menggunakan media sosial, email saja dan menyebar surat seperti kuesioner kepada alumni secara manual.

4. Pelacakan alumni menggunakan kuesioner online yang terkomputerisasi.

5. Dengan sistem yang ada sebelumnya membutuhkan waktu yang lama dan sangat tidak efektif Kecepatan sistem dalam menyampaikan informasi dan pengoperasikan oleh alumni dan petugas. 


\section{Sistem Desain dan Kontruksi}

Setelah diketahui kebutuhan pengguna selanjutnya dibuat analisa kebutuhan pengguna untuk mengetahui interaksi antara aktor dengan sistem menggunakan Usecase Diagram. Aktor yang terlibat adalah administrator, bagian RPU, Kaprodi dan Alumni. Administrator bertugas melakukan pengelolaan pengguna sistem. Bagian RPU memiliki akses role seputar mengelola data alumni, membuat kuesioner dan mengelola data kuesioner. Sedangkan kaprodi melihat hasil pengisian kuesioner yang dilakukan oleh alumni dan melihat data sebaran alumni. Alumni memiliki akses role mengisi kuesioner dan melihat data sebaran alumni yang telah terisi.

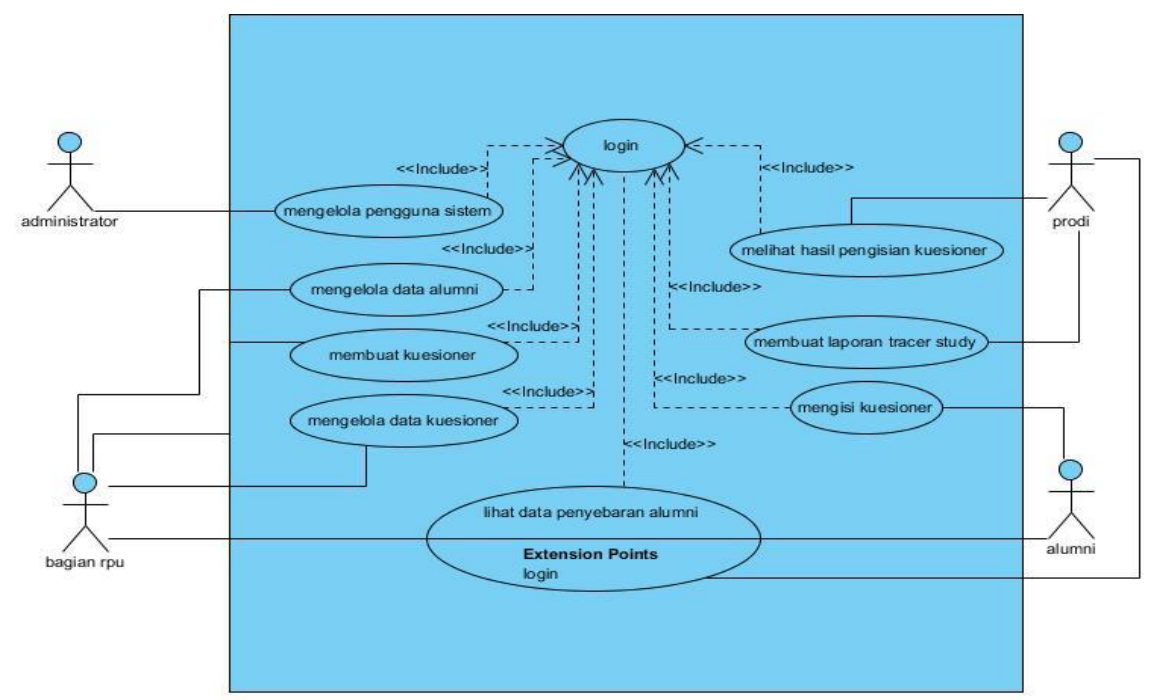

Gambar 1 Usecase Diagram Tracer Study 
Setelah melakukan analisa pengguna menggunakan usecase digram yang menggambarkan behavior sistem, tahap selanjutnya adalah membuat class diagram. Pada class diagram dapat diketahui atribut dan method yang digunakan pada class. Adapun class yang didesain pada penelitian tracer studi ini ada 10 class diagram diantaranya adalah: class alumni, class employmenthistory, concentration, user, employe, province, city, questionare, questionareResult, quetionareAnswer.

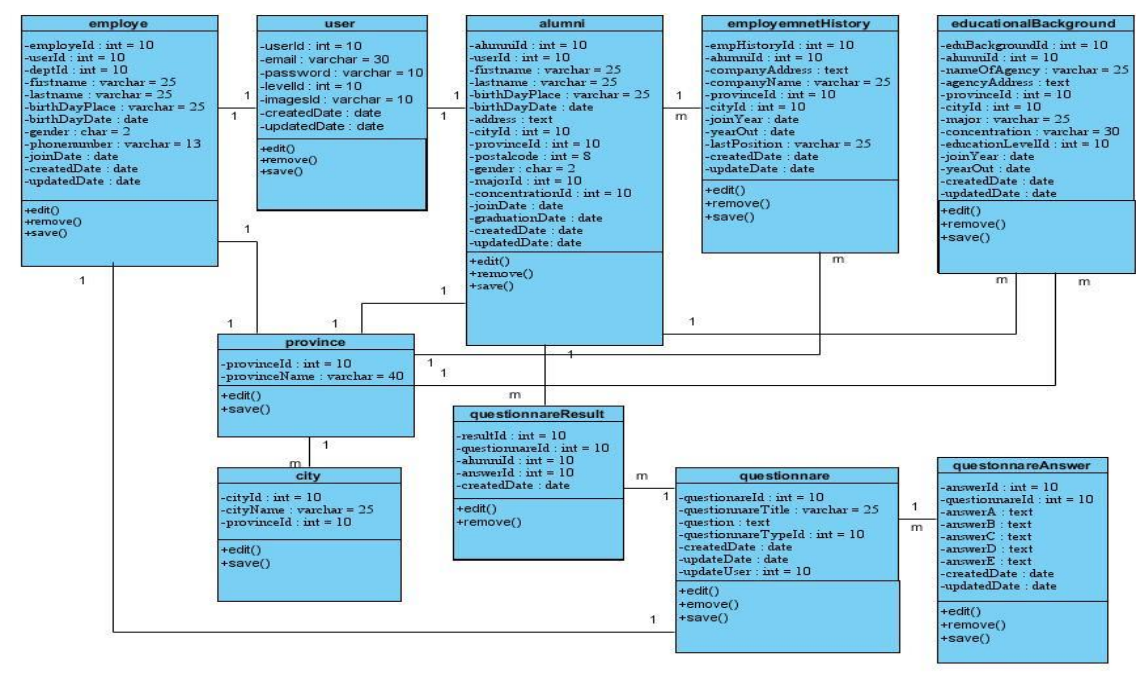

Gambar 2 Class Diagram Tracer Study

\section{Membangun Prototype}

Berdasarkan survei kebutuhan pengguna dilakukan pembuatan prototype yang dibangun dengan rancangan awal perangkat lunak yang berpusat tampilan view (format input dan output sistem serta graphic user interface). Aplikasi trace study yang dikembangkan memiliki fitur diantaranya adalah: mengelola pengguna sistem, mengelola data alumni, membuat kuesioner, mengelola data kuesioner, mengisi kuesioner, melihat hasil pengisian kuesioner, Membuat laporan Tracer Study dan lihat data penyebaran alumni.

Berikut contoh hasil pengisian kuesioner berupa sebaran data jumlah alumni berdasarkan jurusan yang dapat diakses oleh Kaprodi. 


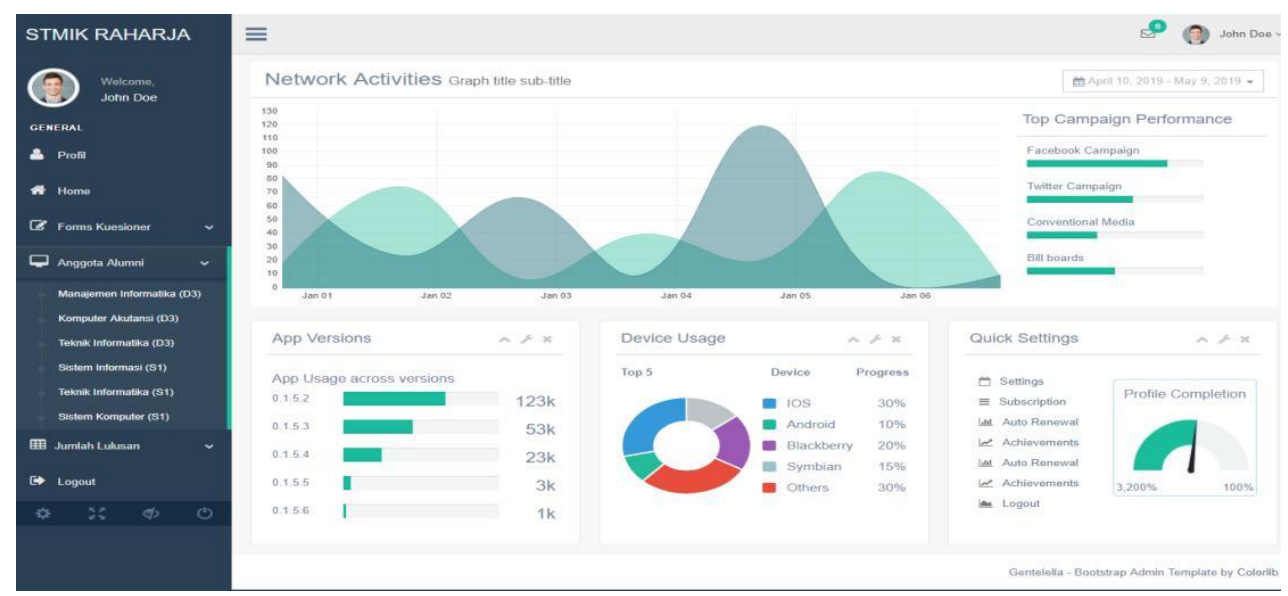

Gambar 3 Grafik alumni berdasarkan Jurusan (Program Studi)

Pada menu form kuesioner ditampilkan data penyebaran kuesioner meliputi: kuesioner riwayat pekerjaan, kuesioner penilaian dosen, kuesioner fasilitas kampus, kuesioner fasilitas lab dan kuesioner pekerjaan lulusan Berikut ini adalah tampilan untuk alumni mengisi kuesioner.

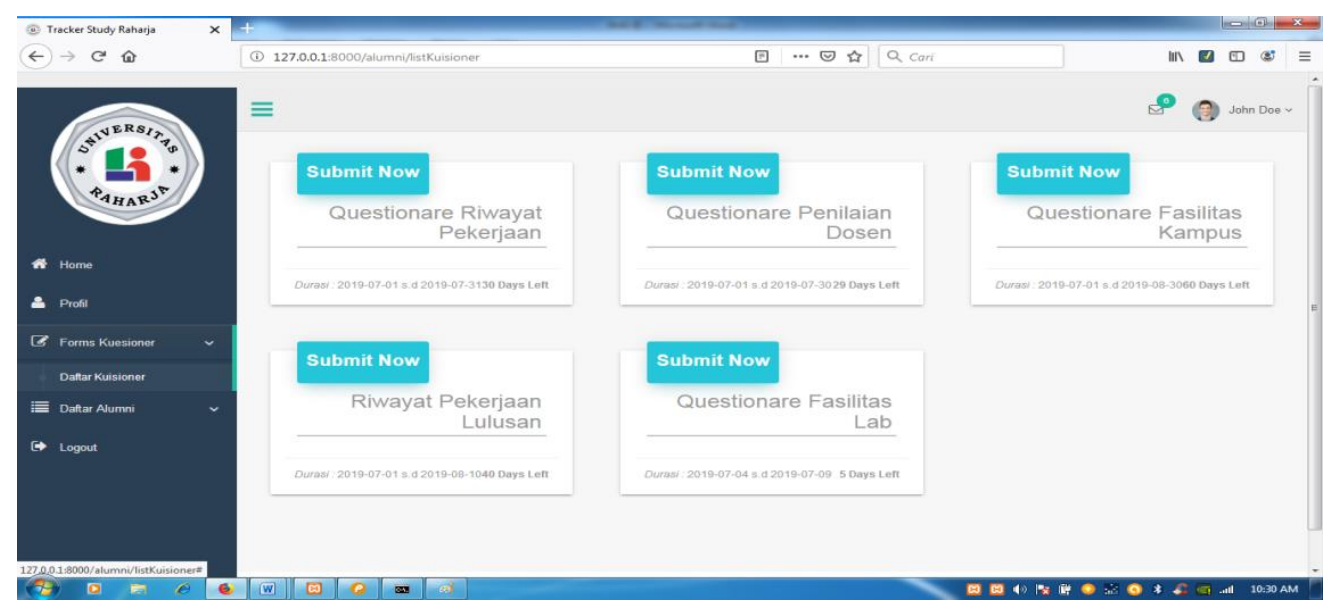

Gambar 4 Form isian kuesioner alumni 


\section{Pengujian Sistem}

Metode pengujian sistem pada Aplikasi Tracer Study ini adalah menggunakan black box testing. Pengujian dilakukan untuk mengetahui apakalah modul-modul yang digunakan pada sistem tracer study ini telah layak atau belum. Pengujian modul pada area sistem login, profile user, register, kuesioner dan data alumni.

\begin{tabular}{|c|c|c|c|c|c|}
\hline No & $\begin{array}{l}\text { Skenario } \\
\text { Pengujian }\end{array}$ & Text case & $\begin{array}{l}\text { Hasil yang } \\
\text { diharapkan }\end{array}$ & Hasil pengujian & Hasil \\
\hline 1 & $\begin{array}{l}\text { Pengujian } \\
\text { terhadap menu } \\
\text { login }\end{array}$ & $\frac{-}{G}$ & $\begin{array}{l}\text { Admin yang berhasil } \\
\text { masuk akan di } \\
\text { arahkan ke tampilan } \\
\text { dashboard }\end{array}$ & $\overline{0} 0$ & Valid \\
\hline 2 & $\begin{array}{l}\text { Pengujian } \\
\text { terhadap login } \\
\text { salah }\end{array}$ & 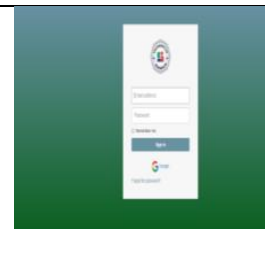 & $\begin{array}{ll}\text { Sistem } & \text { akan } \\
\text { menampilkan } & \\
\text { kesalahan dan } & \text { harus } \\
\text { melakukan } & \text { login } \\
\text { kembali } & \end{array}$ & (8.) & Valid \\
\hline 3 & $\begin{array}{l}\text { Pengujian } \\
\text { Terhadap Profile } \\
\text { User }\end{array}$ & Frome & $\begin{array}{l}\text { Sistem akan } \\
\text { Menampilkan Profile } \\
\text { User }\end{array}$ & $\begin{array}{l}0= \\
\cdots \\
\cdots\end{array}$ & Valid \\
\hline 4 & $\begin{array}{l}\text { Pengujian } \\
\text { tehadap register }\end{array}$ & 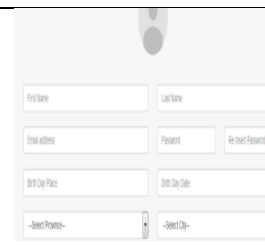 & $\begin{array}{l}\text { Menampilkan menu } \\
\text { login }\end{array}$ & 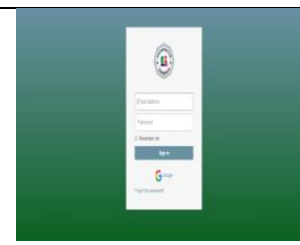 & Valid \\
\hline 5 & $\begin{array}{l}\text { Pengujian } \\
\text { terhadap } \\
\text { kuesioner } \\
\text { alumni }\end{array}$ & 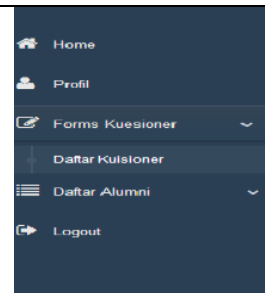 & $\begin{array}{l}\text { Sistem akan } \\
\text { menampilkan } \\
\text { kuesioner }\end{array}$ & 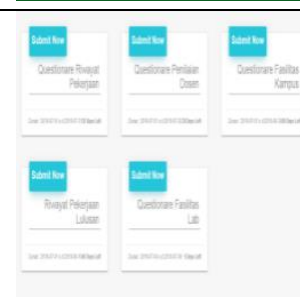 & Valid \\
\hline 6 & $\begin{array}{l}\text { Pengujian } \\
\text { terhadap data } \\
\text { alumni }\end{array}$ & 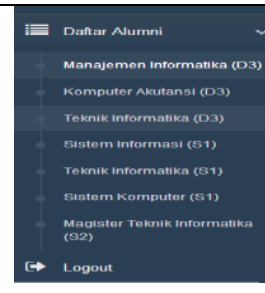 & $\begin{array}{l}\text { Sistem akan } \\
\text { menampilkan data } \\
\text { alumni }\end{array}$ & (3) & Valid \\
\hline
\end{tabular}

Tabel 1 Black box tracer study 


\section{KESIMPULAN}

Sistem Pengelolahan Tracer Study ini dibuat untuk membantu pihak universitas dalam menelusuri data alumni yang dimana informasi tersebut digunakan untuk mengukur dan mencari kinerja lulusan sehingga dapat diperoleh indikator yang jelas tentang profil lulusan dari program studi Universitas Raharja. Selain itu, sistem ini juga didesain dengan fungsi- fungsi yang dapat memberikan kemudahan dalam menyimpan dan mengolah data alumni. Sistem Tracer Study yang dibuat menjadi sebuah aplikasi berbasis web menggunakan laravel framework. Aplikasi ini telah dilakukan pengujian menggunakan blackbox testing sehingga aplikasi ini layak untuk digunakan oleh Universitas Raharja sehingga pihak universitas dapat mengetahui outcome pendidikan dalam bentuk transisi dari dunia pendidikan tinggi ke dunia kerja, penguasaan terhadap kompetensi, evaluasi proses pembelajaran dan penggalian terhadap sosiobiografis lulusan Universitas Raharja.

\section{DAFTAR PUSTAKA}

[1] A. Nasuha and K. Siahaan, "Analisis dan Perancangan Sistem Informasi Alumni (Tracer Study) Berbasis Web pada IAIN Sulthan Thaha Saifuddin Jambi," J. Manaj. Sist. Inf., vol. 1, no. 1, pp. 18-29, 2016.

[2] Z. A. Nugroho and R. Arifudin, "Sistem Informasi Tracer Study Alumni Universitas Negeri Semarang Dengan Aplikasi Digital Maps," Scienfitic J. Informatics, vol. 1, no. 2, pp. 153-160, 2014.

[3] F. Luthfi, "Penggunaan Framework Laravel Dalam Rancang Bangun Modul BackEnd Artikel Website Bisnisbisnis.id," JISKa, vol. 2, no. 1, pp. 34-41, 2017.

[4] K. Fahriya, "Rancang Bangun Simawa (Sistem Informasi Rusunawa) Berbasis Web Application Menggunakan Framework Laravel," J. Manaj. Inform., vol. 8, no. 2, pp. 121-128, 2018.

[5] Y. A. Prasetyo, N. Ambarsari, P. Studi, S. Informasi, and U. Telkom, "Pengembangan Web-Ecommerce Bojana Sari Menggunakan Metode Prototype," in e-Proceeding of Engineering, 2015, vol. 2, no. 1, pp. 1042-1056.

[6] B. C. Neyfa and D. Tamara, "Perancangan Aplikasi E-Canteen Berbasis Android dengan Menggunakan Metode Object Oriented Analysis \& Design (OOAD)," J. Penelit. Komun. dan Opini Publik, vol. 20, no. 1, pp. 83-92, 2016.

[7] E. Nursubiyantoro and Puryani, "Perancangan Sistem Penelusuran Alumni (Tracer Study) Berbasis Web,” J. OPSI, vol. 9, no. 2, pp. 85-92, 2016. 